\title{
EREBEA
}

Revista de Humanidades

y Ciencias Sociales

Núm. 5 (2015), pp. 71-88

ISSN: 0214-0691

\section{LA ENCRUCIJADA DEL IsLAM (Y DE LA IsLAMOLOGÍA)}

\author{
Emilio González Ferrín \\ Universidad de Sevilla
}

\section{RESUMEN}

La Islamología española debe refundarse teniendo en cuenta una doble encrucijada: la renovada atención internacional en torno al llamado Early Islam, y los necesarios desconfesionalismo y des-ideologización de los estudios científicos (honrados) tanto sobre el islam como sobre el Islam. En ese sentido, proponemos una lectura de la entendible como Antigüedad Tardía Islámica sólo a la luz de los testimonios de su tiempo. Al hacerlo así, aparece el islam en tanto religión diferenciable como un producto de lenta decantación, no culminada con visos ciertos de reconocimiento histórico hasta las primeras décadas de los años 800 .

Palabras Clave

Islamología; Antigüedad Tardía Islámica; Presentismo; Early Islam;

Fecha de recepción: 1 de sept. de 2015

Fecha de aceptación: 30 de octubre de 2015

\section{Abstract}

The Spanish Islamology must be refounded considering a double crossroads: the renewed international attention on the so-called Early Islam, and the necessary distance from confessional or ideological studies about Islam taken as scientific attainments. In that sense, we propose a reading of the so called Islamic Late Antiquity understandable only in light of testimonies of their time. While doing so, Islam appears as a product of slow decanting, not culminated with historical recognition until the early decades of the 800 s.

\footnotetext{
KEYWORDS

Islamology; Islamic Late Antiquity; Presentism; Early Islam;
} 

En su reciente reconstrucción teórica de la Islamología, Aaron W. Hughes justifica su esfuerzo de redacción ante el patente malentendido, comúnmente extendido, acerca de lo que suele entenderse como estudios académicos sobre el islam. Tales estudios -afirma- se presentan últimamente como insulares y apologéticos, movidos por un ambiente general ecuménico y fenomenológico, interesado en primer término en conceptos etéreos como verdad, autenticidad, experiencia y significado ${ }^{l}$. El resultado final de esa apología alegórica de una alteridad sería, para este autor, la manufactura de un determinado islam artificial ${ }^{2}$ por medio de herramientas retóricas y metalenguaje hermenéutico. Tal resultado final artificioso -añadimosincluiría una serie ininterrumpida de discursos, ora apologéticos -decía-, ora difamadores, que pasan por académicos. Estas páginas tratan de sumarse a ese esfuerzo por reconstruir la disciplina académica de la Islamología.

\section{ISLAM E ISLAM}

La Islamología o Islamística, como adelantó en el siglo pasado el padre Pareja -ese préstamo del italiano, Islamistica, se debe sin duda a la mano de Alessandro Bausani, omnipresente en la obra de Félix Pareja ${ }^{3}$-, tiene un claro objeto de estudio que en español incluye un problema providencial, puesto que lo islámico puede referirse tanto al Islam (cultura, civilización) como al islam (religión). Tal

1 Hughes, Aaron W. (2012), Theorizing Islam. Disciplinary Deconstruction and Reconstruction. Durham: Acumen, pág. 2.

2 Compartimos sin reservas esta idea de la manufactura y lo artificioso referido a la Islamología. Estas páginas recogen diversas reflexiones basadas principalmente en las sesiones y trabajos presentados sobre el tema en Teherán, Irán (Universidad Allamah Tabatabai, "Corán: traducción y manipulación", diciembre 2014 y mayo 2015), Aarhus, Dinamarca ("Artifactual side of Early Islam", mayo 2015), y Milán, Italia (Nangeroni Meeting, "Islamic Late Antiquity and Fath: the effect as cause"). El marco en que se inscribe mi participación en tales sesiones es doble: el proyecto $\mathrm{I}+\mathrm{D}+\mathrm{i}$ HAR2013-45578-R (Universidad Complutense de Madrid), y el continuo intercambio de ideas producido en la forja del Early Islamic Studies Seminar (EISS). Mi agradecimiento especial desde aquí a Najmeh Shobeiri (Teherán), Anders Klostergaard Petersen (Aarhus) y por encima de todo a mis colegas y maestros del EISS, Carlos A. Segovia, Guillaume Dye y Manfred Kropp.

3 Debe adelantarse también que las mismas ideas y deudas que aquí se expresan animan un trabajo de próxima aparición: el prólogo a la reedición de la monumental Islamología del padre Pareja a cargo de la editorial Athenaica, hecho que celebramos como refundación de la propia Islamología española, una disciplina expropiada por un arabismo hiper-especializado al socaire de un medievalismo hispano altamente ideologizado. 
mínima diferenciación ortográfica resulta-decíamos- providencial porque viene a marcar dos entidades, dos realidades distintas, pues verdaderamente existen esos dos ámbitos diferenciables, y si en otros idiomas no se mantienen las mismas fronteras léxicas o siquiera ortográficas (incluido el árabe; sobre todo el árabe) es por polisemia de un término, no por inexistencia de tal dualidad conceptual, necesariamente resaltable.

En puridad, deberían ampliarse también hasta un tercer ámbito las posibles referencias a lo islámico, ya que el término tiene también connotaciones sociológicas contemporáneas desligadas, o al menos claramente diferenciables, de lo exclusivamente religioso o lo estrictamente histórico y cultural, ajeno esto en gran medida a esa contemporaneidad antes aludida. En resumidas cuentas, entendemos que lo islámico puede referirse a tres ámbitos distinguibles; tres espacios intelectuales a los que se dedica la Islamología:

1. El islam como religión (ámbito de lo personal), o bien como sistema religioso, colectivo, corporativo dogmático. En este ámbito, el estudioso debe ser mero notario y asumir la importancia, nada en absoluto científica y a todas luces creciente, del razonamiento analógico-poético personal, teológico, especulativo.

2. El Islam (obsérvese la mayúscula) en tanto que civilización históricamente reconocible como Dar al-Islam y que abarcó desde la presencia palpable del Bagdad abbasí en torno a los primeros años 800 , hasta la disolución del califato sunní de Estambul en 1924. Todo cuanto se salga de este marco cronológico no debería comprenderse como Dar al-Islam, debido a que lo anterior a los ańos 800 es más bien compleja suma de historias locales sin la afinidad cosmopolita islámica clásica; afinidad colectiva que se perdió tras 1924, al margen de recuperaciones teóricas parciales, anacrónicas y utópicas. Este arco cronológico es susceptible de todo tipo de correcciones y matizaciones posibles, pero su fecha de inicio, en torno al 800 , se fundamenta en cuanto veremos más adelante acerca de la encrucijada del Islam en sus comienzos, así como su fecha final, 1924, simboliza el auge de los nacionalismos locales desmarcados ya de una clara identidad colectiva previa (histórica, cultural) islámica. El cambio cualitativo que supuso ese año 1924 en el sunnismo (abolición del califato por el proyecto nacionalista de Atatürk) comparte época con un discurso similar en el entorno chií, como consecuencia de la revolución constitucional iraní de 1907 (revolución malograda tras el golpe de 1925 y la instauración de la dinastía Pahleví, que por otra parte nacionalizó aún más ese discurso histórico, ya nacional iraní, en las fechas que nos ocupan), así como similares localismos nacionalistas en el subcontinente indio, como el año 1929 y la Conferencia de Musulmanes de la India (nacionalización proto-pakistaní). Es probable 
que el canto de cisne de Dar al-Islam fuera el panislamismo salafista de finales del XIX, pero nos conformamos con enunciarlo aquí para poder desarrollarlo en otro momento.

3. El Islam como marco sociológico contemporáneo con que designar a las tierras habitadas por musulmanes, colectivamente identificados como tales. En inglés se viene usando hace tiempo el término Islamicate para este Mundo Islámico. En este sentido, el islam actúa como referencia colectiva, utópica y simbólicamente unitaria, para millones de musulmanes que en realidad se han educado en identidades nacionales desligadas entre sí (incluso identidades nacionalistas enfrentadas) y que viven o proceden de países y espacios tan diferenciados como Turquía, Irán, Subcontinente indio, Malasia e Indonesia, las exrepúblicas soviéticas de Asia Central, los cuatro conjuntos geopolíticos del mundo árabe -léase, Magreb, Machreq, Golfo, Valle del Nilo-, así como el Islam africano, el Euro-Islam, o The Nation of Islam en Estados Unidos, por citar los grupos más relevantes desde el punto de vista demográfico. El estudio de todos y cada uno de ellos, decíamos, entraría en este tercer ámbito de los estudios islámicos, la Islamología, pero evidentemente también en el de la Sociología o Antropología. Y qué decir de los estudios estrictamente geopolíticos, estratégicos y políticos de toda índole, siempre tan atentos a lo islámico.

Religión, civilización, sociedades contemporáneas. Tres islames claramente diferenciables y fundidos sólo en la confusión mental de apologetas o difamadores. Por cerrar este capítulo: la obsesión taxonómica de academicismos disfrazados de criterios científicos diluyó la necesaria visión de conjunto (opuesta a la mezcla, por cierto) que sólo la Islamología puede ofrecer en todo lo relacionado con lo islámico. Porque las visiones reduccionistas crean fantasmas interpretativos: el creyente es mal analista ${ }^{4}$, y el positivismo histórico difícilmente entiende de entidades evolutivas, cambiantes. Por ejemplo, ¿Cómo puede hablarse de un solo Islam? ¿Cómo plantear con cordura que el Islam abbasí pueda ser el mismo sujeto histórico que el Imperio turco o el almohade, o que exista siquiera una singularidad religiosa, homogénea en el tiempo, en torno a la palabra islam? Por otra parte, los estudios religiosos comparados difícilmente son lo suficientemente orgánicos, adaptables. Necesitan clasificar y equiparar modelos de vertebración ahistórica -profetología, antologías arcaicas, excepcionalidades humanas-, que acaban aplanando idiosincrasias y proyectando lo propio por ajeno. Finalmente, con los estudios sociológicos y geopolíticos ocurre algo similar: no pueden dete-

4 Dans les sciences humaines, autant que la trop grande distance, la trop grande proximité entre le chercheur et l'objet de sa recherche fait problème. Stroumsa, Guy G. (2015), "Le parcours d'un flâneur". Sesión Academia.edu 20.8.2015, https://www.academia.edu/s/63a73eb01d, pág. 11. 
nerse demasiado en la distinción entre causas y efectos; su aritmética no sospecha siquiera la proyección geométrica de la materia tratada, el crecimiento orgánico de las cosas en el tiempo y el espacio.

Por tanto, y sin que desmerezca un ápice ni una sola de esas especialidades y cualquier otra que pueda acercarse ocasionalmente a algún aspecto de lo islámico, el reto de la Islamología contemporánea es recuperar su sitio abovedado: todo lo que atañe a cualquiera de los tres citados ámbitos de lo islámico, siendo su epítome deseable su posible lectura de conjunto, siendo incuestionable un cierto distanciamiento científico, y siendo recomendable que ofrezca el mapa pausado de una diversidad. Precisamente consiste en esto último el valor principal de la Islamología: mostrar la diversidad, negada desde la mayor parte de los análisis metonímicos sobre cualquier aspecto de lo islámico, que siempre toman la parte descontextualizada por el todo ignorado.

Y precisamente también, tratando de mostrar esa visión de conjunto, nuestra idea de lo islámico no puede ser en modo alguno esencialista o unitaria sino circunstancialista y diversa, dado que -por ejemplo- consideramos los orígenes y la evolución del islam y del Islam interdependientes pero en modo alguno relacionados entre sí en un proceso de causas y efectos. Es decir, y volviendo a nuestro tema favorito en numerosos trabajos anteriores, dado que lo consideramos como la gran piedra de toque interpretativa de los diversos islames: jamás, en modo alguno, puede o debería considerarse al islam como el sustento ideológico de una cadena de invasiones que clausuró la Antigüedad Tardía, dando paso a la Edad Media. El paradigma Pirenne del Islam alienante, sustentado religiosamente por el islam y entrando a saco en la historia del Mediterráneo, es el estigma que pasea el positivismo histórico a la hora de armar (literalmente) un espacio contra-cultural islámico. De ahí, nuestra obsesiva referencia a la no-conquista unitaria islámica, de la que volvemos a dar indicios ahora al marcar ya nuestra interpretación de arranque, que siempre resumimos en tres ideas simples, genuino Rubicón de nuestra postura intelectual en materia de Islamología:

1. Diversidad y unidad. De una diversidad previa, acabaría resultando una relativa unidad religiosa y una cultural en torno a los primeros ańos 800 . No al contrario, como suele aceptarse; esa idea quimérica de una determinada unidad de mensaje y comunidad de la que iría derivando todo el Islam mediante diversificación. Tanto el islam como el Islam se generaron en un cruce de caminos, razón ésta de nuestra simbólica encrucijada en uso. El primero (islam) no generó al segundo, sino que el segundo (Islam) se legitimó generando (manufacturando) la realidad aumentada del primero.

2. Causas y efectos. Dado que el islam no es la causa del Islam, sino que ambos son el efecto final de innumerables decantaciones, ensayo y error de mil y un proyectos de centralización política e intentos de ortodoxia 
unitaria, toda percepción inductiva del hecho religioso (islam) alimentando un hecho cultural (Islam) partiendo de una adolescencia conquistadora (futūh) es una pésima y simplista interpretación de los complejos procesos históricos que tuvieron lugar en Oriente Medio desde los años 300 a los 800. El islam no generó la llamada conquista islámica o árabe de medio mundo conocido. Una religión no es culpable de la (sólo aparente) discontinuidad entre las edades Antigua y la Media. Esa interpretación es un parapeto ideológico medievalista y (lo que es peor) medievalizante.

3. El reto de no traducir términos esenciales, como suele recomendar Daniel Boyarin (the task of untranslation); la palabra islam o musulmán, incluso el término Corán aplicado a un libro concreto, se convierten en anacronismos al ser aplicados a la lectura inducida del tiempo concreto que ahora nos ocupa: porque utilizar el término musulmanes en los años 600 y 700 es incurrir en algo que veremos a continuación, presentismo. Pero anacronismo y presentismo no son lo más grave referido a estos problemas de traducción; lo realmente grave es utilizar un solo término posterior (musulmanes) para traducir variados y numerosos términos que aparecen en no menos numerosas crónicas de los años 600 y que tratan los desórdenes bélicos de aquellos años, indudable consecuencia de un repliegue imperial: una retirada de la Romania (Bizancio) y Persia del palenque próximooriental.

En aquellas crónicas pre-árabes se deja constancia del caos ocasionado por la intervención de (y utilizamos aquí exactamente el modo en que aparecen esos pueblos invasores en crónicas tales): Judíos, Sarracenos, Magharitae, Hijos de Agar, Tayyaye, Hijos de Ismael, Árabes, Caldeos, Asirios, Estirpe de Ismael, Tayikos, Clanes judíos, Agarenos, Pueblos de Gog y Magog... Todas esas referencias, algunas de ellas míticas, otras parcialmente reiteradas, y muchas de ellas referidas a la arabidad en tanto que modo de vida alternativo no metropolitano, son traducidas sistemáticamente por musulmanes en las recopilaciones posteriores, o por árabes sin más explicación en las interpretaciones actuales. Los esfuerzos contemporáneos por delimitar un pueblo o comunidad embrionaria concreta y única como causante del efecto dominó del Islam pasan por la forja de nuevos términos genéricos, siendo las más célebres los agarenos ${ }^{5}$ o creyentes $^{6}$. En nuestra opinión, modos nuevos de volver a esa matriz del Islam por no seguir el procedimiento más acertado: no traducir esos nombres, aceptar la complejidad de las cosas; dejar que

5 Crone, Patricia, y Cook, Michael (1977), Hagarism. The Making of the Islamic World. Londres-Cambridge: Cambridge University Press.

6 Donner, Fred M. (2010), Muhammad and the Believers. At the Origins of Islam. Cambridge (EEUU): Harvard University Press. 
la diversidad onomástica originaria nos ofrezca pistas de la no menos diversa realidad histórica. Porque utilizar un solo término para traducir diversos conceptos es apuntar ideológicamente a una única alienación invasora, a la medida de, por ejemplo, la dualidad medieval entre el Islam y Occidente; dualidad medieval muy contemporánea, por cierto ( $\mathrm{y}$ de ahí nuestra anterior alusión a lo medievalizante, rasgo inequívoco de nuestras sociedades actuales).

En tal sentido, el de ir interpretando los orígenes del islam y el Islam como efecto y no causa, así como diversidad originaria que dio paso a una (matizable) unidad islámica posterior (un sistema religioso, una civilización), se mueve lentamente la enorme maquinaria academicista en torno a los estudios históricos y teológicos, si bien lo hace ruidosamente y anatematizando interpretaciones novedosas que posteriormente asume como propias. Por ejemplo, ya sólo algún que otro despistado sigue hablando de conquista islámica, pues se viene admitiendo canónicamente el enorme salto cualitativo de una matización: la conquista árabe. Es un salto interesante, si bien sigue siendo una terminología errónea, qué duda cabe: el singular es el problema principal, esa obsesión por la unidad previa. Pero también es errónea la confusión que se crea al agrupar tantos pueblos diversos bajo la bandera lingüística del árabe.

EL PROBLEMA EPISTEMOLÓGICO SOBRE LOS ORÍGENES DEL ISLAM Y DEL ISLAM.

En esta breve reflexión sobre los orígenes del Islam y los retos de la Islamología al respecto, pretendemos sentar las bases generales para posibles interpretaciones futuras parciales en cualquiera de las ramas de la Islamología o sus numerosas ciencias colaterales. Bases como la diversidad formativa del Islam (encrucijada 1, la del Islam) que puedan ir sustentando una nueva lectura de conjunto (encrucijada 2, de la Islamología).

Al tratar aspectos históricos, nuestra elección personal metodológica es el campo genérico de la Historiología, que incluye un concepto al que solemos llamar Geopolítica de la Historia. Si la Historiología se ocupa de los grandes mecanismos de la Historia, aprovechando la Filología y tantas otros saberes al servicio de la interpretación del ritmo de los tiempos, acuñamos esta expresión (Geopolítica de la Historia) para marcar un desajuste cultural elevándolo al rango de hábito a lo largo de los siglos: el aprovechamiento geopolítico contemporáneo (de cada contemporaneidad aprovechadora) de un recurso compartido como es la Historia. Resulta evidente que la historia es siempre una narración que mira al futuro, ya que siempre se interpreta a la medida de expectativas. En esa lógica, no ya difusa sino incluso algo caótica (por la inevitable personalización de los discursos y sus consecuencias), se enmarca el que entendemos como principal problema a la hora de analizar o tratar de comprender el Islam: el problema epistemológico que se plantea al presuponer una coherencia, un orden (nada menos que divino, en algunos casos), en el proceso formativo del primer Islam. El presentismo en 
que se incurre en tal interpretación (asumir en el pasado un cierto orden previo providencial, curiosamente sólo comprensible desde el presente) consiste en aplicar el llamado proceso de continuidad retrospectiva, mediante el cual se suelen situar en tiempos remotos realidades y conceptos ordenados y coordinados muy posteriormente.

En ese sentido, proponemos la lectura de las épocas sólo a la luz de los testimonios de su tiempo. Al hacerlo así, aparece el islam en tanto religión diferenciable como un producto de lenta decantación, no culminada con visos ciertos de reconocimiento histórico hasta-decíamos- las primeras décadas de los años 800. Fijémonos en esas fechas: solemos relacionarlas con el apogeo de una ciudad, Bagdad, cuya construcción se comienza en el 762 y que a partir de esas citadas décadas comienza a repintar sus blasones partiendo de un proceso que hoy comprendemos como consecuente, porque conocemos su capitulación histórica posterior, y que (por lo mismo) confundimos con una cierta lógica previa. Es decir: se tiende a proceder a una lectura minimalista (del islam al Islam mediante conquista) de un enorme desorden maximalista que abarcó a todo el Oriente Medio y el Mediterráneo al menos desde los años 300 hasta los 800. Dicho de otro modo: desde el presente se dota de coherencia consecuente al errático discurrir de la Historia.

El error de base es comprender como cadena de acontecimientos históricos cuanto desde Bagdad se narra (inventa, modela; manufactura) como lógica histórica previa legitimadora de una presencia institucional: la dinastía Abbasí. El salto literario desde Medina a Bagdad, pasando por Damasco, sólo adquiere la primera persona del verbo a partir de los ańos 800 . Y esta idea de la artificiosidad, esencial para comprender historiológicamente la evolución de los primeros islames, sólo podrá ser refutada con la aparición de algún texto anterior al 800 que plantee en primera persona la expansión del islam hasta llegar al Islam. La citada presunción de lógica en estos procesos históricos (aplicada, decíamos, desde el patente presentismo del positivismo histórico) plantea una matriz profética islámica supuestamente armada como sistema religioso y modo de vida socio-político desde primeros de los años 600 en Medina (aún Yatrîb) abriéndose paso en la historia mediante una magistral combinación de irrefrenable persuasión anímica personal ante el carisma profético y un imparable poderío militar que no solamente eclosionó como Imperio sino que fagocitó a los grandes de su tiempo (la Romania y Persia), clausurando con ello la Edad Antigua.

Evidentemente (y esto significa según las evidencias con que contamos), el Islam no hizo nada de eso. De hecho, el Islam no hizo nada en sus primeras etapas formativas, sino que fue hecho. Cuanto será reconocible históricamente mucho después como Islam no nació como tal, sino que fue nacido por innumerables circunstancias. De ahí la ausencia coherente (y elocuente) de toda referencia a la primera persona del verbo en tantas crónicas como se conservan anteriores a las árabes de los años 800. Porque (y aquí incluimos una reflexión de conjunto que 
planteamos como crucial) el llamado Early Islam, el período formativo del primer Islam, no trata los primeros pasos de esa entidad histórica (Dar al-Islam) sino su período de gestación, previo (como es sabido) al nacimiento.

Por eso insistimos tanto en que el islam no es el motor ideológico del Islam como causa de una era medieval convulsa, sino el efecto final, la decantación de un desorden generalizado producido por diversas causas y que a los efectos teológicos se reconoció y fue reconocido en tanto que sistema religioso. A los efectos políticos, desde diversas capitales (primero Bagdad) se acabó pivotando una Dar al-Islam constituida por entidades metropolitanas yuxtapuestas, cohesionadas colectivamente por un sentido de sistematización religiosa común forjada a posteriori (islam) y en realidad unida solamente por una densa y fructífera red de conexiones comerciales.

Aquel presentismo, cuanto se conoce como la falacia del nunc pro tunc (el ahora por el entonces, los parámetros actuales aplicados a tiempos en que no existían, tales como cuanto hoy consideramos como religión, entre otros) es una de las dos grandes facetas del enorme problema epistemológico en torno a los estudios islámicos, siendo la otra una gran falacia argumental: el recurso a la autoridad. Inexplicablemente, los trabajos al respecto se inundan de pies de páginas ${ }^{7}$ y débitos claustrales con que introducir un enorme ruido autoritario que desvíe la atención del cauto, alejándolo de la lógica de los procesos y llevándolo hasta un academicismo autopoiético cuyas redes de sustento se confunden con el propio objeto de estudio.

Ambas facetas del problema epistemológico en torno a los estudios islámicos, y especialmente cuando se trata el Early Islam (presentismo del nunc pro tunc y falacia del recurso a la autoridad), se alimentan de un anacrónico (si bien valiosísimo, a otros efectos) manantial documental medieval: las crónicas árabes tal y como se redactaron desde mediados de esos ínclitos años 800. Es decir (y la noticia de esto deja boquiabiertos a los historiadores que se ocupan de otras épocas o civilizaciones): para describir el Oriente Medio de los ańos 600 se concede magnánimamente el rango de fuente primaria a crónicas elaboradas ;dos siglos después! Los historiadores positivistas cometen así dos errores. El primero es directo: asumir que se puedan describir los hechos de aquel tiempo concreto (años 600) tal y como se narran desde la distancia de doscientos años después de los hechos acaecidos. También cometen un grave error indirecto, porque hay crónicas de aquella primera época, hay fuentes primarias; decenas de documentos coetáneos referidos a esos hechos de los años 600, pero son crónicas parciales. Están redactadas en idiomas distintos del árabe (golpe difícilmente esquivable a los estudios

7 No habrá pasado desapercibido que, en este trabajo de reflexión, sólo utilizamos el espacio de los pies de página cuando la idea expresada proviene claramente de otro trabajo o autor concreto, y no para introducir ruido gregario. 
árabes expropiadores de los estudios islámicos) y están hablando de pueblos diversos, no del Islam. Todo ello es interpretado a la luz de esas crónicas árabes muy posteriores (de ahí su carácter de error indirecto, decíamos). Se inventa desde el después, y ese después traduce, retoca, interpreta, las fuentes coetáneas del entonces. Las únicas fuentes realmente válidas se trastocan de este modo. Fuentes que pueden arrojar luz suficiente, por cierto, siempre que se contextualicen.

De entre todas esas crónicas árabes posteriores canonizadas, probablemente las más emblemáticas son las de Al-Tabari (839-923) y Al-Mas'udi (896-956), así como la recopilación bibliográfica mítica de Ibn al-Nadim (m. 995). Esos grandiosos materiales literarios (tardíos y en árabe) constituyen y sustentan un enorme sistema de referencia inercial que a su vez proyecta de un modo historicista otro sistema paralelo, coetáneo, al que otorga rango de antigüedad y autoridad: el círculo cerrado literario constituido por el Corán, las biografías del Profeta, y la recopilación de hadices (dichos, hechos y silencios del profeta Mahoma); círculo probablemente construido sobre la base de las primeras relaciones biográficas atribuidas a Ibn Ishaq $(\mathrm{m}$. 767) y en realidad recogidas más tarde por Ibn Hisham (m.833). Y acostumbrémonos a estos saltos cronológicos: siempre que haya referencia a una obra anterior a los 800 resultará que sólo se conoce por redacciones posteriores a esos 800 . Pues bien: el primer sistema referencial creado (y entrelazado) por esos grandes autores citados, así como el segundo sistema referencial manufacturado en torno a ellos (las antologías arcaicas sustentadoras de las ortodoxias islámicas) actúan sobre las posibles realidades históricas producidas en los años 600 al igual que el positivismo histórico muy posterior actúa sobre todo ese tiempo en curso: recurso a la autoridad, lo llamábamos. Presentismo, detectábamos.

Lo interesante del caso es que, por debajo de todo ese aparato autoritario triple (círculos viciosos de referencia recíproca de ortodoxia religiosa, cronística árabe e historiadores corporativos contemporáneos a nosotros) existen numerosos elementos, desde crónicas hasta monedas y realizaciones artísticas y arquitectónicas, que nos permiten sospechar una compleja trama argumental, alternativa a esos comienzos del Islam como entidad auto-propulsada por un mensaje profético desde Meca hasta Bagdad, e incluso también desde Poitiers (al Oeste) hasta el Jurasán (al Este) y más allá. Pero esa trama argumental alternativa es algo más complicada que la Historia Oficial de caballerías milagrosas y fe inquebrantable. Por añadidura, tal trama alternativa incluye elementos interpretativos desdeñados desde el presentismo; por lo que el valor de toda esa información directa queda minimizado y sobre todo manipulado desde el mucho después. ¿Qué nos ofrecen esas crónicas no árabes de los años 500 y 600, única base documental del paleoIslam (es decir, el periodo de gestación del Islam, no sus primeros pasos)?: 
A. Desde lo puramente histórico:

- Diversidad e incoherencia maximalista de los pueblos involucrados en tantas acciones bélicas entre mediados de los 500 y los 800 , así como una fértil fricción cultural (¡lingüística!) entre ellos, que posteriormente se condensará como una polinización reciproca, una simbiosis y forja compartida de sistemas lingüísticos concretos.

- Agotamiento y repliegue de imperios diversos, colapsos de dinastías, migraciones.

- Continuidad arquitectónica y artística. Invisible conquest, la llamó Pentz ${ }^{8}$.

- También, acuñación competitiva de monedas y sellos desde Inglaterra hasta Asia Central. Véanse, a este respecto, las monedas inglesas en árabe acuñadas por el rey Offa de Mercia en torno al $780^{\circ}$. Desde ahí se acunó moneda con leyenda en árabe por todo el Mediterráneo Sur hasta Irán (no incluido, por lo general), así como se solaparon rutas comerciales nuevas y se sustituyeron (se angostaron o se ahorcaron) las clásicas. Esos sellos y monedas, como el citado dinar inglés acuñado por el rey Offa, serán tomados como prueba de invasión islámica (insistimos: últimamente invasión árabe). Hecho sobre el que no cabe mayor comentario que la mofa acerca de la invasión árabe o islámica de Inglaterra a mediados de los 700. O la no menos risible invasión árabe de un sistema cultural tan compacto como el iranio; un territorio que contribuirá a la forja del Islam sin arabización.

B. Desde lo puramente religioso, se fueron decantando las largas disputas entre comunidades o facciones no tan fáciles de distinguir o etiquetar. Hablar del islam como una herejía del judeo-cristianismo, en este sentido, es tan ajustado a la realidad como hablar de una herejía judeo-cristiana que se desgajó del islam, entendido éste aquí como posible continuidad de unas consideraciones monoteístas de largo recorrido a las que se sumaron novedades ortodoxas como la paternidad divina (idea nada novedosa en general, pero sí en los ámbitos monoteístas). Este razonamiento crítico no podrá entenderse desde la consideración positivista y cronológica de los procesos religiosos.

Pero, es que ¿̇realmente nace el islam en la hégira, 622, o bien es una delimitación convencional establecida posteriormente? ¿Nace el islam, o se produce una nueva distribución de sistematización religiosa? Es evidente que por esos alrededores se están decantando unos sistemas religiosos que, por ejemplo, no van a aceptar (pongamos por caso) una cristología mesiánica, o bien una cristología de

8 Pentz, Peter (1992), The Invisible Conquest: The Ontogenesis of Sixth and Seventh Century Syria. Copenhagen: National Museum of Denmark Collection of Near Eastern and Classical Antiquities.

9 Milwright, Marcus (2010), An introduction to Islamic archaeology. Edimburgo: Edinburgh University Press, pág. 51. 
relaciones divinas paterno-filiales. Sean cuales sean los ingredientes, las fisuras, la nueva distribución de parcelas ideológicas, sociales, lingüísticas, hay una cosa evidente que nos interesa aquí sobremanera: lo que nace (o es nacido) lo hace desde dentro, en tanto que cambio o evolución, no como invasión alienante. El islam no viene: emerge. La invasión es un disfraz posterior.

En este sentido, en el del islam primigenio, podemos abundar algo más en las disputas teológicas (genuina decantación social de un tiempo): durante siglos, la consideración de Jesús el nazoreo como hijo de Dios y mesías, o bien solo mesías, podía marcar las fronteras entre comunidades de fe, todas ellas englobables como corrientes de un cierto monoteísmo a granel. Un monoteísmo ambiental aún en vías de etiquetado exclusivista. ¿No podría considerarse al islam como parte igualmente antigua de todo ese debate? Jesús sería sólo profeta, puede que también Mesías ${ }^{10}$; una facción ideológica sólo después considerada como sistema religioso delimitada y aparte. En tal sentido, si el futuro islam participa desde dentro de un viejo debate mediterráneo y próximo-oriental, ¿por qué, cuándo, cómo se forjó la leyenda del islam como religión periférica, venida, llegada desde fuera?

Evidentemente, el islam es una religión surgida de las diversas polidoxias que coincidieron y se constituyeron por contraste, por reacción entre sí. No es una incorporación invasiva. Sólo a partir de la polarización ideológica medieval se consolidará esa dicotomía, ese paradigma de Pirenne -decíamos- sobre lo islámico como incorporación de lo ajeno a lo Mediterráneo, una consideración que el Islam constituido como civilización asumirá como propia, prefiriendo la opción del éxodo a la de la transformación. Resulta también evidente que la Islamología debería tener algo que decir en el cómo y por qué ha ido cambiando nuestra percepción del primer Islam en las últimas décadas. Incluso puede plantear con qué espera contribuir en este proceso científico. En el resto del mundo se está haciendo; sólo cabe que esta propuesta de resurrección de la Islamología española se sume al proceso.

\section{Continuidad RETROACTIVA.}

En su imprescindible libro La muerte de un profeta, Shoemaker aporta dos razonamientos paliativos para nuestro problema epistemológico; la tesitura, la encrucijada, ante la que se encuentra la Islamología al interpretar el sentido histórico real del primer Islam. En primer término, da por sentada la adecuación de una conocida metodología en el ámbito concreto de los estudios coránicos: la que ya se aplica a los estudios bíblicos. ¿Cómo no van a poder aplicarse al Corán las mismas técnicas comparativas y de análisis textual que se emplean desde hace siglo y medio en los estudios bíblicos? En segundo lugar, apuesta sin reservas

10 Segovia, Carlos A. (2015), "En torno a Mahoma como Mesías. Una nueva mirada a las raíces cristianas del islam". Erebea: Revista de Humanidades y Ciencias Sociales, 5. 
por una interpretación del proceso constitutivo del islam semejante a nuestra descripción de la narración retrospectiva, destacando la continuidad retroactiva que se establece, que se finge, al narrar desde un contexto ideológico determinado, y muy posterior, cuanto se entiende como los actos fundacionales de un proceso, indudablemente en aras de una legitimidad, no en honor a la verdad ${ }^{11}$. Así, Shoemaker plantea que el Islam abbasí re-mitologizó la historia formativa del movimiento para adecuarse a las nuevas circunstancias ${ }^{2}$. Definitivamente, el conjunto de la obra de Stephen J. Shoemaker supone un soplo de aire fresco en la Islamología de este siglo.

En realidad, por más que aprovechables desde la Islamología, esos válidos planteamientos de Shoemaker provienen del ámbito específico de los estudios religiosos. No es ésta una reserva exclusivista, sino precisamente inclusivista: a esas acertadas disquisiciones sobre el islam habrá que añadirle otras semejantes sobre el Islam, a menos que sigamos anclados en la confusión polisémica. Es decir: en el acto narrativo de continuidad retroactiva que desde el Bagdad abbasí construyó la previa tradición fundacional islámica, fueron trenzados dos procesos paralelos que deberíamos desentrañar. Por un lado, la evolución de las ideas religiosas. Por otro lado, el salto de la Antigüedad Tardía a la Media debida al agotamiento imperial de dos civilizaciones que conectarán y a veces se fundirán en el Islam posterior: Bizancio y Persia. El primer lado atañe a los estudios religiosos, el segundo a los históricos. Corresponde, pues, a la Islamología, trazar los mapas comprensibles de tal trenzado. Es decir: desde lo puramente islamológico, se debe destacar el paralelismo de una evolución religiosa y acontecimientos históricos que llevarán a la constitución del Islam civilización. En tanto no se acepte este paralelismo (la existencia de un par en movimiento), seguiremos anclados en la unicidad invasiva y profética de la matriz islámica religiosa en un cambio de era, y tendremos que seguir remando contra la marea de los estudios gregarios en materia de Islamología, que aún se basan en un ahistórico Big Bang muhammadí.

Una ayuda esclarecedora es denunciar la falacia clásica del petitio principii (petición de principio; dar por supuesto un punto inicial cuestionable) a los orígenes del islam, del Islam, y de sus protagonistas. Porque, a menudo, damos por sentadas interpretaciones posteriores, pensando que son originarias. Hemos visto que es anacrónico aplicar el término islámico a un tiempo en que ni se usaba ni se entendía su idea como diferenciadora. También hemos visto que hoy se prefiere plantear la opción árabe; arabizar todo el proceso invasivo y confundir los heterogéneos movimientos de tantos y diversos árabes (de toda condición religiosa,

11 González Ferrín, Emilio (2013), La angustia de Abraham. Los origenes culturales del islam. Córdoba: Almuzara, pág. 14.

12 Shoemaker, Stephen J. (2012), The Death of a Prophet. The End of Muhammad's Life and the Beginnings of Islam. Filadelfia: University of Pennsylvania Press, pág. 268. 
por ejemplo, así como de enorme dispersión geográfica) con un centralismo profético vertebrador. Ocurre con los árabes de las crónicas latinas (así como con los sarracenos en las crónicas griegas anteriores) como con los bereberes del norte de África. Es evidente que las denominaciones de los pueblos suele ser exógena; suelen ser llamados desde el otro lado del río, por así decirlo: bereber, por ejemplo, es el que no está latinizado (barbarus). Sarraceno (sarrakenoi), el no helenizado (y posteriormente no latinizado tampoco), etcétera. Pero colegir de ahí una clara y única identidad bereber o sarracena es una aportación contemporánea tan exitosa como improbable. Asumir la vertebración religiosa de tales campos semánticos es, simplemente, una construcción. Un artificio.

Pues bien: las denominaciones genéricas establecidas desde fuera o desde el después (como es nuestro caso con los árabes), confieren una homogeneidad irreal a lo denominado. Los árabes, en tanto que pobladores de Oriente Medio, hablantes de una multiplicidad de lenguas árabes en diversos alfabetos (ninguno de ellos era el actual, probable evolución del alfabeto siríaco en torno a los años 500), vivieron ocasionales alianzas de tribus o clanes, a veces para oponerse a poderes ajenos o a veces para sumarse a ellos contractualmente. Tal es el papel de lo árabe como sociedad heterogénea en la larga historia del enfrentamiento entre Roma y Persia en Oriente Medio. En tal situación de heterogénea ambigüedad, proponemos fijarnos en una época concreta, probable cesura histórica desde el año 570 hasta el 627. Y expliquemos la razón de presentar esas fechas: en torno al año 570 se admiten comúnmente dos acontecimientos de muy diversa índole. Uno es el nacimiento del profeta Mahoma (sin prueba alguna). Otro es menos legendario: la definitiva destrucción de la presa yemení de Maarib, que ocasionó la migración al norte (Arabia) de algunas decenas de miles de pobladores.

La otra fecha propuesta para nuestro estudio de caso, la final, decíamos, es 627: la llamada batalla de Nínive, punto resolutivo del enfrentamiento abierto entre los imperios bizantino y persa. No hay que entrar en el ámbito de lo especulativo para sospechar novedades demográficas en el norte de Arabia y región de Siria desde la llegada de contingentes humanos desde el sur (árabes por su lengua y modo de vida nómada obligado en el caso de los flujos migratorios) a partir de ese 570 probado. Conocidas son las incorporaciones de tribus árabes enteras al servicio de alguno de los dos imperios en aquellas décadas (y desde mucho antes). Sin embargo, ¿qué pudo haber ocurrido después de ese 627 con el cese de las hostilidades entre ambos imperios? Las crónicas de la época lo especifican abiertamente: las intervenciones bélicas que antes se hacían en nombre de uno de los Imperios (las crónicas suelen ser hostiles al Persa) ahora parecen hacerse por cuenta propia.

De hecho, alguna de las crónicas es elocuente al respecto: Sofronio, por ejemplo, obispo de Jerusalén fallecido en el 638, describe los desórdenes de su tiempo estableciendo una continuidad con las invasiones persas que utilizan a tropas sa- 
rracenas. Sólo en la mente confusa de los siglos posteriores se entenderá sarraceno como sinónimo de árabe y (en salto mortal) de musulmán; pero sólo en una mente muy cerrada puede colegir una invasión repentina tras esa crónica de Sofronio, que culmina llamando a las tropas imperiales (que ya no actuarán, replegadas desde la paz de Nínive) para que (y citamos): sometan la loca arrogancia de los sarracenos, para asi humillarlos bajo los pies del emperador, como antes (negrita nuestra) ${ }^{13}$. El cronista no siente un tiempo nuevo, y menos aún sospecha matrices religiosas exógenas que vengan a clausurar su época.

Ya hemos tratado estas cuestiones en trabajos anteriores; el modo en que todas esas crónicas coetáneas a los desórdenes de los tiempos nunca perciben la presencia de una religión nueva que empuja, sino una religión vieja en vías de partición. De hecho, en la mentalidad de los tiempos, la referencia religiosa asociada a los desórdenes no es directa sino indirecta y mito-referencial: los saqueos de ciudades, pueblos, monasterios, son una penitencia buscada debida a los pecados de Calcedonia $^{14}$; la sobredimensión social y política de un endémico debate teológico en varios Concilios (mal llamados hoy, pues eran Sínodos) de la Iglesia acerca, muy especialmente, de la naturaleza de Jesús el nazoreo. En esas crónicas coetáneas no hay un pueblo invasor: hay un final de los tiempos.

Al comparar esas crónicas pre-árabes con las árabes (a partir de mediados de los 800 , desde ese Islam ya generado en torno a Bagdad), solemos establecer una diferencia dramática y literaria, en sentido estricto: mientras que en las crónicas pre-árabes destaca una concepción apocalíptica del mundo, y nunca tienen voz propia los muy diversos contingentes humanos que se dedican al pillaje de las ciudades, ante la debilidad coercitiva de un Bizancio en repliegue, en la segunda oleada de crónicas (ya árabes, ya abbasíes, ya estableciendo la continuidad retroactiva legitimadora de su autoridad) destaca la clara secuencia de un pueblo en movimiento, semejante a la narración veterotestamentaria del Éxodo y los éxitos bélicos hasta hacerse con la Tierra Prometida. Por fin, en esa segunda oleada, aparece la primera persona del verbo. En el movimiento cronístico desde mediados del 500 hasta mediados del 800, un mecanismo a dos tiempos incurre en evidentes incoherencias narrativas: desde la sístole inicial, apocalíptica, de las crónicas pre-árabes, hasta la diástole del pueblo en marcha de las crónicas árabes. La segunda serie de crónicas, aquellas por fin árabes, incorporan como elemento narrativo esencial el arranque creacionista profético.

Es evidente que ante el relato oficial de una invasión con llamada profética estamos ante otro caso más de cuanto se entiende como Historia contrafactual: la narración mítica de cuanto pudo haber sido (o cuando debió haber sido) sin

13 Flori, Jean (2010), El islam y el fin de los tiempos. La interpretación profética de las invasiones musumanas en la Cristiandad medieval. Madrid: Akal, pág. 100.

14 González Ferrín, (2013), La angustia de Abraham..., pág. 335. 
comprobación real. Al igual que el Éxodo, decíamos. Al igual que Roma alimentó y vivificó la leyenda de Alejandro Magno y de Eneas para servirse de ellas como legitimidad mítica propia (un pequeño Estado como Roma podía llegar así de lejos; era la refundación de Troya, etcétera), los abbasíes de los 800 construyeron un relato mítico que los legitimaba religiosamente a dos bandas, y así llevaban a cabo el antes citado trenzado de lo religioso e histórico. Su primera legitimación es directa: los abbasíes decían provenir de la familia del Profeta. La segunda es indirecta: hemos acabado con los Omeyas, aquellos que masacraron a la familia del Profeta. Bagdad inventaba haber acabado con Damasco; justificaba la entrada definitiva de la tradición persa (lo abbasí es evidentemente persa) en el Mediterráneo creando la narración de una escalada geográfica desde Meca a Medina, Damasco y Bagdad. En esa segunda búsqueda de legitimación, el elemento persa hacía su entrada triunfal en la forja del Islam: el mito de Kerbalá y la muerte de Huseín a manos de los Omeyas (Shimr como brazo ejecutor del califa Omeya Yazid) legitimaban desde lo islámico religioso al poder persa establecido en Bagdad. Nacía el Islam y se narraba el islam a su medida, partiendo de una invasión conceptual narrada para mayor gloria de una dinastía y tomada por verdad sin comprobación crítica.

La Islamología no puede partir de la narración mitica que los practicantes de una religión se cuentan a si mismos para dar sentido a su mundo ${ }^{15}$.

\section{ISLAMOLOGÍA}

Aprovechamos esta cita anterior para terminar con una glosa al necesario trabajo de Aaron H. Hughes con que arrancaban estas páginas: su Teorizando sobre el islam: deconstrucción y reconstrucción de una disciplina ${ }^{16}$. Ya desde los agradecimientos, adelanta el autor su rechazo a aceptar como verdadero tanto lo heredado como lo establecido ${ }^{17}$, sentando así las bases de un correctivo teórico que no deberá tener en cuenta los supuestos discursos de autoridad, ya sean religiosa o academicista. También maneja desde el primer momento la palabra islam en plural (islams $)^{18}$, de necesaria retención conceptual pese a la parquedad de su uso (por dificultades hasta fonéticas), así como plantea un principio general: si una disciplina pierde su lado crítico, se arriesga a proclamar medias verdades como si fueran principios genéricos; algo que puede derivar en osificación intelectual ${ }^{19}$.

La disciplina de la Islamología no puede basarse en las hagiografías de fundadores ni en fuentes tardías y cuestionables presentadas como testimonios. No debe asumir que el núcleo o esencia del Islam está en el profeta Mahoma; alguien

15 Hughes (2012), Theorizing..., pág. 23.

16 Original, en ingles: Theorizing Islam: Disciplinary Deconstruction and Reconstruction.

17 Hughes (2012), Theorizing..., pág. i.

18 Op. Cit. Pág. 6.

19 Op. Cit. Pág. 7. 
sobre quien no sabemos prácticamente nada pese al respeto reverencial que se le pueda profesar (necesaria des-religiosización de la Islamología), como tampoco se debería actuar corporativamente contra quienes no comparten las visiones mayoritarias, acusándolos de no contar con la formación metodológica adecuada ${ }^{20}$ porque las ciencias se angostan siempre desde el centro. Ese uso selectivo de las metodologías es cuanto en otros lugares hemos denominado metodologismo, el primo pobre de la ciencia y muy útil para ferroviarios, pies de página y acreditaciones, pero inútil a la hora de aportar ideas.

Hughes apuesta por reconstruir los estudios académicos sobre el Islam sin tener en cuenta los discursos impuestos ${ }^{21}$, y es en este punto en el que cerramos y nos sumamos a reconstruir una Islamología española que probablemente llegó a su punto culminante con nombres como Miguel Asín Palacios (1871-1944, defenestrado hoy día por razones ideológicas, marca de la desorientación ambiental española en materia científica; o quizá más bien la orientación siempre ideológica) o Félix María Pareja (1890-1983). Añadiríamos a estos dos nombres el de Mikel de Epalza (1938-2008), para dejar constancia de que una vez hubo Islamología en España (aunque no siempre en español: probablemente una de las mejores traducciones del Corán a lenguas occidentales es la que Epalza realizó en catalán). No entraremos en las razones de un repliegue científico en un siglo $\mathrm{XX}$ español complejo. Lo cierto es que la obsesiva especialización arabista y medievalista en el Islam andalusí (al servicio del africanismo español), así como la reactiva especialización en la Literatura árabe contemporánea (por aquellos que no quisieron sumarse al anterior subproducto africanista) han dado innumerables frutos contables como logros de un arabismo, decíamos, muy especializado. Pero los estudios islámicos no deberían seguir atomizándose en manos de estudiosos que no pueden tener esa antes aludida visión de conjunto sobre lo islámico.

La Islamología española, la producida en español, puede refundarse en la doble encrucijada que aquí señalamos: la atención internacional en torno al llamado Early Islam, y los necesarios des-confesionalismo y des-ideologización de los estudios científicos (honrados) tanto sobre el islam como sobre el Islam. 